\title{
Recent advances in treatment of acute coronary syndromes Bhuvnesh Aggarwal ${ }^{1}$ and Venu Menon ${ }^{2 *}$
}

\author{
Addresses: ${ }^{1}$ Departments of Internal Medicine, 9500 Euclid Avenue, Cleveland, Ohio 44114, USA; ${ }^{2}$ Cardiovascular Medicine Cleveland \\ Clinic, 9500 Euclid Avenue, Cleveland, Ohio 44114, USA \\ *Corresponding author: Venu Menon (menonv@ccf.org) \\ Fl000Prime Reports 2013, 5:56 (doi:10.12703/P5-56) \\ This is an open-access article distributed under the terms of the Creative Commons Attribution-Non Commercial License \\ (http://creativecommons.org/licenses/by-nc/3.0/legalcode), which permits unrestricted use, distribution, and reproduction in any medium, \\ provided the original work is properly cited. You may not use this work for commercial purposes. \\ The electronic version of this article is the complete one and can be found at: http://fl000.com/prime/reports/m/5/56
}

\begin{abstract}
In this manuscript we highlight recent advances in the management of acute coronary syndromes. Efforts to minimize myocardial ischemia time through improved health care systems have resulted in significant success. In addition, new evidence in the areas of reperfusion therapy and pharmacological intervention has emerged. Percutaneous coronary intervention continues to evolve and new data concerning the superiority of the radial route, the use of improved stents and adjunctive therapy will be presented. We will highlight the changes that were made in international guidelines (from the American College of Cardiology/ American Heart Association and the European Society of Cardiology) in the last 18 months in order to incorporate the latest evidence. Although significant advancements have been made in the management of acute coronary syndromes, the morbidity and mortality associated with this condition remains high, necessitating continued research in this field of cardiovascular medicine.
\end{abstract}

\section{Introduction}

Cardiovascular mortality remains the leading cause of death across the globe. In this manuscript, we review major new updates in the area of acute coronary syndrome (ACS) including ST-segment elevation myocardial infarction (STEMI), non ST-segment elevation myocardial infarction (NSTEMI) and unstable angina. We attempt to summarize major publications and presentations relating to the management of ACS including improvements in systems of care for STEMI, new drugs for immediate and post intervention care after ACS and newer therapeutic approaches. We also report on updates in the guidelines for the management of ACS from the European Society of Cardiology (ESC) and the American College of Cardiology Foundation/American Heart Association (ACCF/AHA).

\section{Improved systems of care for STEMI}

Standard guidelines recommend a door-to-balloon timetime from first medical contact to primary percutaneous coronary intervention (PCI) - of less than 90 minutes (according to the ACCF/AHA) or 60 minutes (according to the ESC) for patients presenting with STEMI. A large proportion of patients, however, do not receive mechanical reperfusion in this time frame. Although there has been debate regarding the implementation of regional care systems to improve access to acute PCI $[1,2]$, such efforts have been previously shown to reduce door-to-balloon times and improve outcomes in patients with STEMI [3]. A recent retrospective study on nearly 100,000 patients with STEMI in the US revealed that, while there have been significant improvements in nationwide door-to-balloon times (from a median 83 minutes in 2005-2006 to 67 minutes in 2008-2009), such efforts have not translated into a reduction in in-hospital mortality [4]. This study highlights the fact that door-to-balloon time constitutes a fraction of the total myocardial ischemia time that begins at the time of symptom onset and ends after successful reperfusion. Further gains in door-to-balloon times without significant reduction in total ischemia time are unlikely to have any further impact on overall patient outcomes. It is imperative that quality initiatives should aim not only for lower door-to-balloon time but for early symptom recognition, pre-hospital triage, treatment and transport. In the past year, evidence has emerged that direct transport of STEMI patients to a more distant PCI capable center (rather than to a nearer non-PCI center) leads to shorter overall 
reperfusion times and increased adherence to standard guidelines [5]. Additionally, retrospective analysis data comparing the two triage strategies has suggested that mortality may also be considerably reduced with direct transfer to a PCI center, bypassing the non-PCI center [6]. In a French registry, significant reductions in mortality were noted between 1995 and 2010, largely attributed to reductions in time from symptom onset to first medical contact, greater use of reperfusion therapy, and guideline recommended pharmacotherapy [7].

While optimal primary PCI is the established and preferred reperfusion regimen, a significant proportion of subjects still present to institutions without timely access to a PCI laboratory. Although prompt fibrinolysis in these patients has been advocated, evidence supporting this strategy was limited. The STREAM trial randomized 1,896 STEMI patients presenting within 3 hours of symptom onset who could not reliably undergo PCI within 1 hour [8]. Subjects were randomized to primary PCI or fibrinolysis before transfer to a PCI capable hospital. There were no significant differences between groups in the primary endpoint - a composite of death, shock, congestive heart failure and reinfarction up to 30 days. This is the first study demonstrating comparable efficacy of fibrinolysis and primary PCI in patients with STEMI who may not have access to timely PCI. However, there was a five times higher incidence of intracranial hemorrhage in the fibrinolysis group over the primary PCI group $(1.0 \%$ vs. $0.2 \%, P=0.04)$ leading to a mid-trial amendment for dose reduction of the fibrinolytic agent (tenecteplase) to $50 \%$ in patients $>75$ years of age. This strategy led to the avoidance of early angiography in nearly two-thirds of patients in the fibrinolysis group. The long term outcome differences, however, remain to be seen. A different analysis suggested that increasing the number of centers performing PCI has not increased access to PCI for patients with STEMI in the US. This is because the increase in PCI centers has mainly been in population locales with prior PCI centers and has therefore resulted in competition between centers but not enhanced access for the population at large [9].

\section{Recent advances in medical therapy for ACS Antiplatelet therapy \\ Prasugrel}

Prasugrel was initially compared to clopidogrel in a large randomized trial (TRITON-TIMI 38) for ACS patients who were scheduled to undergo PCI. Based on the promising results from this trial (superior efficacy, albeit with a higher bleeding risk), the agent was approved for patients with ACS scheduled to undergo percutaneous intervention. A large proportion of patients with NSTEMI/ unstable angina-also known as non ST-segment elevation/acute coronary syndrome (NSTE-ACS) are however managed medically and do not receive early revascularization. Results from a large study on medically managed ACS patients, the TRILOGY ACS trial, were recently published [10]. This study randomized 9,326 patients with NSTE-ACS to receive either prasugrel (10 $\mathrm{mg}$ for $<75$ years and $5 \mathrm{mg}$ for $>75$ years) or clopidogrel. At a median follow up of 1.7 years, the results were neutral with similar efficacy and comparable bleeding risk with both agents. Although largely a negative trial, TRILOGY did provide several new insights into the use of prasugrel. Firstly, this study confirmed the safety and efficacy of the reduced dose of prasugrel $(5 \mathrm{mg})$ in patients $>75$ years of age. Secondly, a pre-specified analysis on patients who were randomized after a diagnostic angiogram revealed superior efficacy of prasugrel compared to clopidogrel with a $23 \%$ reduction in the primary efficacy endpoint of cardiac death, myocardial infarction or stroke. A similar benefit was not uncovered in patients randomized before a diagnostic angiogram [11]. In another study (the ACCOAST trial), pretreatment with prasugrel at the time of clinical diagnosis of NSTE-ACS was not associated with a reduction in adverse cardiovascular events, but was associated with a higher incidence of major bleeding complications [12].

\section{Ticagrelor}

Ticagrelor is the first oral, reversible $\mathrm{P}_{2} \mathrm{Y}_{12}$ receptor blocker that provides a rapid, consistent and more effective antiplatelet effect than clopidogrel. It was initially compared with clopidogrel in patients with ACS in the PLATO trial, results of which demonstrated improved efficacy outcomes (including reduced mortality) with similar rates of major bleeding [13]. Pre-specified subgroup analysis from the PLATO trial in medically managed patients with ACS demonstrated similar results to the overall cohort with a reduction in mortality $(6.1 \%$ vs. $8.2 \%$; $P=0.01)$ and a slightly higher incidence of major bleeding $(11.9 \%$ vs. $10.3 \% ; P=0.08)$ using ticagrelor compared to clopidogrel [14]. On subset analysis, the observed benefit with ticagrelor was limited to patients with elevation in high sensitivity troponin [15].

Current ESC guidelines give a Class I recommendation to ticagrelor, prasugrel and clopidogrel in the setting of an ACS event. However, clopidogrel is reserved only for patients who cannot receive either ticagrelor or prasugrel (due to lack of availability or contraindications) making the other two the preferred antiplatelet agents. Ticagrelor is also recommended in patients with a moderate (those with elevated troponin) or a high risk of ischemic events, regardless of initial management strategy chosen (early invasive or conservative). For prasugrel, the recommendations state that it should be utilized only in patients 
with ACS in whom the coronary anatomy is known and who are proceeding to PCI.

In contrast, current ACCF/AHA guidelines endorse both clopidogrel and ticagrelor for patients with ACS without preference of one over the other. In cases when the coronary anatomy is known, all three agents are considered equivalent with no specific preference. Finally, in patients with NSTE-ACS managed conservatively (unlike STEMI), clopidogrel and ticagrelor are recommended equally with no mention of prasugrel.

\section{Vorapaxar}

Protease activated receptor-1 (PAR-1) is a primary receptor for thrombin on platelets and is also present on vascular endothelium and smooth muscle cells. Vorapaxar is a novel oral PAR-1 antagonist that inhibits thrombininduced platelet activation, a mechanism that is entirely different from those of other available antiplatelet agents. Vorapaxar was tested as an adjunctive agent in patients with NSTE-ACS in the TRACER trial [16]. This study randomized 12,944 patients with NSTE-ACS to receive vorapaxar or placebo along with routine therapy. Over a median follow up period of over 500 days, there was no significant reduction in primary endpoint (death, myocardial infarction and stroke) but there was a substantial increase in major bleeding events $(7.2 \%$ vs. $5.2 \% ; P<0.001)$ and intracranial hemorrhage $(1.1 \%$ vs. $0.2 \% ; P<0.001)$ with vorapaxar when compared to placebo.

\section{Abciximab}

Intravenous glycoprotein (GpIIb/IIIa) inhibitors have considerably gone out of favor for patients with ACS, except in high-risk patients with STEMI. A meta-analysis on upstream abciximab (a GpIIb/IIla inhibitor) use in patients with NSTE-ACS ( $\mathrm{n}=46,374$ patients) revealed only minor improvements in outcomes at the risk of increased bleeding [17]. Current guidelines recommend use of this agent only in high-risk patients who have a high thrombus burden or as a bailout agent in primary PCI.

Even in patients with STEMI, there is a great deal of uncertainty about the preferred route of abciximab administration (intracoronary $v s$. intravenous). The AIDA STEMI randomized trial compared the two routes of abciximab in 2,065 patients presenting within 12 hours of STEMI [18]. Intracoronary and intravenous abciximab resulted in a similar rate of the primary combined endpoint of death, reinfarction, or congestive heart failure at 90 days of follow up. Statistically fewer patients in the intracoronary group had new congestive heart failure $(2 \cdot 4 \%$ vs. $4 \cdot 1 \% ; P=0 \cdot 04)$. The results from an updated meta-analysis confirmed that, although intracoronary abciximab resulted in a significant improvement in myocardial perfusion without any excess of major bleeding, there was no clear mortality benefit with this strategy [19]. Another mechanistic trial (INFUSE-AMI) compared and evaluated intracoronary abciximab and manual aspiration thrombectomy as strategies for prevention of thrombus embolization during PCI in 452 patients with STEMI [20]. The results indicated that abciximab and not thrombectomy reduced infarct size in this patient population.

\section{Duration of antiplatelet therapy}

The duration of dual antiplatelet therapy (DAPT) after PCI with drug eluting stent (DES) remains contentious. Recent evidence from PRODIGY, EXCELLENT and REAL-LATE studies suggest no increase in the risk of myocardial infarction and death and a lower incidence of bleeding complications with DAPT for 12 months as compared to DAPT for longer than 12 months [21]. However, these studies have limitations and evidence is not definitive at this time. Several trials are currently underway that are evaluating a short duration of DAPT (3-6 months) with traditional 12-month therapy (after DES).

\section{Anticoagulation therapy}

Unfractionated heparin vs. bivalirudin

Previously published results from randomized trials (ACUITY in NSTE-ACS, ISAR in NSTEMI, HORIZONSAMI in STEMI) have consistently demonstrated a reduced risk of bleeding and improved overall outcomes with bivalirudin rather than unfractionated heparin (UFH) in ACS patients, giving bivalirudin a class $1 \mathrm{~b}$ recommendation (from ACCF/AHA) as an adjunctive therapy in patients with ACS undergoing primary PCI [22]. The benefits of bivalirudin are mainly in its ability to reduce bleeding risk. With the increased use of radial access and the decreased utilization of intravenous GpIIb/IIIa inhibitors, the cost effectiveness of bivalirudin is up for debate. Retrospective analysis from Sweden's SCAAR database (41,537 consecutive NSTE-ACS patients none of whom received GP IIb/IIIa inhibitors) revealed no benefits from using bivalirudin rather than heparin [23]. Head to head trials comparing bivalirudin with unfractionated heparin (VALIDATESWEDEHEART, HEAT-PPCI) are currently underway.

\section{Otamixaban vs. unfractionated heparin}

Otamixaban is an intravenous, reversible Factor Xa inhibitor, with rapid onset and offset of action and a linear, predictable dose response effect. It was previously tested in patients with NSTE-ACS in the phase II dose finding SEPIA-ACS1 TIMI 42 trial [24]. The results indicated a trend towards improved outcomes with otamixaban at mid-range doses with no significant increase in bleeding as compared to UFH. Results from the phase III superiority trial were presented at the ESC meeting in 2013. This study randomized 3,229 patients with NSTE-ACS and a planned 
early invasive strategy, to otamixaban or UFH plus eptifibatide (at the time of PCI) [25]. There were no reductions in ischemic events (death or myocardial infarction) between the two strategies at 7 days. However, otamixaban was associated with an increased rate of major and minor bleeding $(3.1 \%$ vs. $1.5 \%$; relative risk, 2.13 $P<.001)$. Due to unfavorable safety/efficacy results with otamixaban, the manufacturer (Sanofi) has now discontinued further development of this agent.

\section{Residual risk and use of oral anticoagulants}

Patients with ACS remain at a significant risk of recurrent ischemic events after initial revascularization despite optimal medical therapy including DAPT and aggressive risk factor modification. One in every ten patients experiences a significant atheroembolic event (cardiac death, myocardial infarction or stroke) within a year of the first ACS episode [26]. This is felt to be secondary to a persistent thrombogenic state that extends well beyond the initial ACS event.

Warfarin in the fibrinolytic era has been shown to reduce ischemic events but carries a substantially higher risk of bleeding, and difficulties with drug administration-as well as contemporary reperfusion therapy with primary PCI-have limited its use in this setting. However, several new oral anticoagulants have emerged in the last decade with the potential to minimize residual risk.

\section{Rivaroxaban}

Rivaroxaban is a direct factor Xa inhibitor that ultimately leads to decreased generation of thrombin. Safety and efficacy of rivaroxaban in different doses (5-20 mg) was initially tested in a phase II dose finding trial (ATLAS ACS TIMI-46) that revealed a dose-dependent increase in the rate of bleeding and a reduction in ischemic events in patients with ACS [27]. Subsequently, a larger phase III trial (the ATLAS ACS TIMI-51) was launched that randomized over 15,000 patients with ACS to receive either rivaroxaban ( 2.5 or $5 \mathrm{mg}$ twice daily) or placebo in addition to standard medical therapy [28]. Over a mean follow up of 13 months, there was a $16 \%$ reduction in primary efficacy endpoint (cardiac death, myocardial infarction or stroke) with rivaroxaban as compared to placebo. However, there was a threefold increase in the risk of major bleeding and intracranial hemorrhage. This risk was lower with a reduced dose $(2.5 \mathrm{mg})$ with relatively maintained efficacy. Overall there was a 36\% reduction in all causes of death with low dose rivaroxaban as compared to placebo, which largely derived from a reduction in sudden cardiac deaths. Results were similar in a prespecified subgroup analysis in patients with STEMI [29]. Due to concerns about trial design and missing data $(12 \%$ of patients had incomplete follow up), the FDA voted against recommending approval of the drug for secondary prevention of ACS [30]. However, a $2.5 \mathrm{mg}$ twice daily dose of rivaroxaban was recently approved for the same indication by the European Commission [31]. It should be noted that the approved dose of rivaroxaban for ACS is significantly lower than that used in patients with atrial fibrillation (20 mg or $15 \mathrm{mg}$ in patients with renal impairment).

Although no new data for other new oral anticoagulants (dabigatran, apixaban, betrixaban, darexaban) were presented last year, a meta-analysis of all available studies comparing oral anticoagulants with placebo in ACS revealed modest reductions in cardiovascular events, with a substantial increased incidence of major bleeding with the oral anticoagulants [32]. Future studies are likely to compare oral anticoagulants with newer antiplatelet agents for secondary prevention after recent ACS. The availability of these agents has also increased the scrutiny on the utility of aspirin in niche settings. The WOEST trial compared dual antiplatelet therapy and anticoagulation with clopidogrel and anticoagulation (without aspirin) in patients undergoing PCI and needing oral anticoagulation (mechanical valve, atrial fibrillation) [33]. The study results showed preserved efficacy with much lower incidence of bleeding with this strategy. Whether this benefit extends to the whole spectrum of patients with ACS remains to be seen.

\section{Other novel agents}

\section{Monoclonal antibodies}

Several new therapies and drug strategies for patients with ACS are under investigation. A phase 2 trial (SELECT-ACS) examined a novel P-selectin (a cell-adhesion molecule expressed on endothelial cells and platelets) monoclonal antibody, inclacumab, in patients with NSTE-ACS undergoing PCI [34]. The study randomized 544 NSTEMI patients scheduled for PCI to a placebo infusion or to either a $5 \mathrm{mg} / \mathrm{kg}$ or $20 \mathrm{mg} / \mathrm{kg}$ infusion of inclacumab. There were reductions in troponin I levels at 24 hours after the $20 \mathrm{mg} / \mathrm{kg}$ infusion as compared to placebo, suggesting potential for reducing myocardial damage in this cohort.

\section{Stem cell therapy}

The use of stem cells derived from bone marrow or myocardium to improve cardiac function has been a promising area of research and speculation. Several new studies were presented in the last year with mixed results. The phase 1 CADUCEUS trial enrolled 30 patients with recent myocardial infarction and reduced ejection fraction $(25 \%-45 \%)$ and randomized them in a $2: 1$ ratio to receive autologous cardiac stem cells derived from endomyocardial biopsy (within 1.5-3 months after myocardial infarction) or placebo [35]. Although there were no improvements in ejection fraction at 12 months, 
there was a significant decrease in myocardial scar tissue and an increase in viable myocardium (based on cardiac $\mathrm{MRI}$ ) in the intervention group, as compared to placebo. The TIME (Transplantation in Myocardial Infarction) trial randomized 120 subjects with myocardial infarction and impaired ventricular function that underwent PCI to receive either autologous bone marrow cells or placebo [36]. The patients were randomized to one of four groups: day 3 stem cell (after myocardial infarction); day 3 placebo; day 7 stem cell; day 7 placebo infusions. At 6 months follow up there were no differences in changes in cardiac function (ejection fraction) among any of the groups. Short-term (4 months) results of another study, the SWISS-AMI trial, were also presented at the AHA, Scientific Sessions, 2012 [37]. This trial randomized 200 STEMI patients successfully treated by PCI of the infarct-related artery, in a 1:1:1 pattern to one control and two intracoronary bone marrow-derived stem cell treatment groups (early being 5-7 days or late being 3-4 weeks after STEMI). Cardiac function (assessed on cardiac MRI) did not improve in either of the two groups (early and late stem cell) as compared to placebo at the 4-month follow up. Longer term data (2 years) or the previously published SCIPIO trial was also presented at the same meeting [38]. This study enrolled 30 patients with myocardial infarction and reduced ejection fraction $(<40 \%)$ scheduled for coronary artery bypass grafting (CABG) to receive either intracoronary cardiac stem cell infusion or placebo (randomized in a 2:3 ratio at a mean of 113 days after myocardial infarction). In the 12 patients that received stem cell therapy, there were improvements in ejection fraction, viable myocardium and quality of life at 2 years.

To date, no studies have demonstrated any significant reduction in mortality and have only utilized surrogate parameters such as ejection fraction, myocardial scar tissue and quality of life. Although the above trials are at best hypothesis generating for efficacy of stem cell therapy in ACS, these studies consistently demonstrated the safety of this novel approach. Questions remain regarding the ideal patient population, source of stem cell and timing of infusion to extract maximal benefit from this strategy. Two large randomized trials-the Allogeneic Heart Stem Cells to Achieve Myocardial Regeneration (ALLSTAR, allogeneic cardiac stem cells) and Bone Marrow Cells in Acute Myocardial Infarction (BAMI, autologous bone marrow cells)-are currently enrolling patients and are expected to shed light on some of these unanswered queries.

\section{Hemodynamic support in PCI}

There has been an ongoing debate regarding the utilization of intra-aortic balloon pump (IABP) counterpulsation to support high-risk PCI. Even though there has been a lack of convincing evidence of improvement in outcomes, IABP support continues to be routinely utilized for high-risk patients with myocardial infarction and cardiogenic shock, and international guidelines had given it a Class I indication. To this effect, the IABP-SHOCK II randomized trial was launched to support the routine use of IABP in patients with cardiogenic shock [39]. The investigators randomized 600 patients with acute myocardial infarction (AMI) and cardiogenic shock to IABP or no IABP support. Surprisingly, there were no differences in outcomes across the groups after a 30-day follow up period (no difference in mortality, length of hospital stay, renal function, and vasopressor use). Although the results were largely disappointing and unexpected, there are several caveats to the trial. For instance, only $13 \%$ of the patients received IABP prior to PCI. In addition, there was significant crossover ( $10 \%$ ) between groups that may have had an impact on study results. Despite its limitations, this trial provides reasonably strong evidence against the routine use of IABP after PCI in the setting of cardiogenic shock.

\section{Approaches for PCl: radial vs. femoral access}

Due to patient convenience and the substantial risk of bleeding associated with PCI from the transfemoral route, an alternate radial approach has become popular over the last decade. Previously published observational studies have reported a significantly reduced bleeding risk with radial as compared to a femoral approach for PCI. Several large randomized trials were reported in the last few years that compared radial to femoral PCI for ACS. The RIVAL study randomized 7,021 patients with ACS (managed with a planned invasive strategy) to either the radial or femoral route [40]. Overall, there were no significant differences among the groups for primary outcome (composite of death, stroke, myocardial infarction and non-CABG related major bleeding at 30 days; $3.7 \%$ vs. $4 \%$ ) or incidence of TIMI major bleeding $(0.5 \%$ in both groups). A pre-specified subgroup analysis showed that radial access in patients with STEMI significantly reduced primary outcome (3.5\% vs. 5.2\%; HR: 0.60) and all-cause mortality ( $1.3 \%$ vs. 3.2\%; HR: 0.39) [41]. These differences were not seen in patients with NSTE-ACS. The second trial, RIFLE-STEACS, randomized patients with STEMI to receive primary PCI via radial or femoral access [42]. High-risk patients with cardiogenic shock were also included in this study unlike in the RIVAL trial. The results revealed a $60 \%$ relative reduction in cardiac death via radial access as compared to femoral access (5.3\% vs. $9.2 \%$ ). These differences were attributed to a reduction in mainly access site bleeding after a radial access PCI. Lastly, the RADIAL-STEMI trial randomized 707 patients with STEMI at four centers in the Czech Republic to the two access sites [43]. The investigators reported an $80 \%$ reduction in 30-day bleeding and access site complication 
rate after radial access PCI (1.4\% vs. 7.2\%). Additionally, there was a reduction in contrast load and ICU length of stay after PCI via the radial approach. These trials were primarily conducted on patients in Europe while centers in North America were felt to be under-represented. However, registry analysis from the US also revealed a lower incidence of procedural bleeding and in-hospital mortality after radial access PCI as compared to femoral access PCI in patients with STEMI [44]. These trials provide consistent and convincing evidence that the radial approach for PCI reduces bleeding and access site complications, and improves net outcomes in patients with STEMI. In addition, the radial approach is cheaper, and allows for early patient ambulation, recovery and hospital discharge as compared to the femoral approach. Another interesting conclusion from these studies was the association between improved outcomes and increased procedural experience with radial PCI on the part of interventionists. Importantly, interventionists should ideally aim to master both access sites, since not all patients may be suitable for both approaches. This was evident by $>5 \%$ crossover in these studies. Additional trials comparing the two approaches, namely the MATRIX study ( $\mathrm{n}=6,800$ patients) and SAFE-PCI study (female subjects only), are currently underway.

\section{$\mathrm{PCl}$ in STEMI: preventive $\mathrm{PCl}$ of non-infarct arteries}

Current guidelines recommend against preventive PCI in non infarct-related coronary lesions in hemodynamically stable patients with STEMI at the time of the primary PCI [22]. This recommendation is based on evidence from observational studies or retrospective registry data [45-47]. The Preventive Angioplasty in Myocardial Infarction (PRAMI) trial was a non-blinded trial which randomized 465 patients presenting with STEMI to either primary PCI in an infarct-related artery alone or primary PCI and "preventive" PCI in a non infarct artery with $>50 \%$ stenosis [48]. There was a significant reduction in the primary endpoint, a composite of cardiac death, myocardial infarction and refractory angina in the preventive PCI group when followed over 2 years ( $9 \%$ vs. 23\%; HR: 0.35). There was a trend towards a reduction in mortality although it was not statistically significant. These findings are in sharp contrast to previous retrospective data in this clinical scenario. The study was limited by its small sample size, non-blinding, use of angina as an endpoint and lack of angiographic data. The results call for further randomized trials to answer this important clinical conundrum.

\section{Thrombus aspiration before $\mathrm{PCI}$}

Current ACCF/AHA guidelines recommend routine thrombus aspiration before primary PCI in STEMI (Class IIa) based on the available evidence supporting this therapy $[49,50]$. The registry-based Thrombus Aspiration in
ST-Elevation Myocardial Infarction in Scandinavia (TASTE) trial enrolled 7244 patients with STEMI from Sweden, Denmark and Iceland and randomized them to routine thrombus aspiration or no thrombus aspiration before primary PCI [51]. There were no differences in all cause mortality at the end of 30 days $(2.8 \%$ vs. $3.0 \% ; P=$ 0.63 ). There was a trend towards a reduction in hospitalizations for recurrent myocardial infarction and incidence of stent thrombosis. These neutral results throw into question the practice of routine thrombus aspiration in STEMI. Longterm results of the trial are awaited. Another randomized study-Trial of Routine Aspiration Thrombectomy With PCI versus PCI Alone in Patients With STEMI Undergoing Primary PCI (TOTAL) - is currently underway.

\section{Stent type}

There has been debate regarding the use of drug eluting stents (DES) in patients with STEMI. While DES have been shown to have superior efficacy as compared to bare metal stents (BMS), there have been concerns regarding safety with DES due to incomplete endothelialization and inflammation eventually leading to a potentially higher risk of stent thrombosis. Several studies compared newer DES with BMS and older first generation DES. Second generation everolimus eluting XienceV stents were associated with a lower incidence of stent thrombosis, target vessel revascularization and major adverse cardiac events as compared to BMS [52] and older sirolimus eluting stents after PCI in patients with acute myocardial infarction $[53,54]$. Superiority of DES over BMS was also evident in a network meta-analysis (12,453 patients) comparing the various stent types for patients with STEMI [55]. In contrast, newer second generation zotarolimus eluting Resolute stents had comparable efficacy when compared to the everolimus eluting stents [56,57]. DES with biodegradable polymers have also emerged and were compared with BMS in 1,161 patients with AMI in the COMFORTABLE trial [58]. The primary endpoint (composite of cardiac death, target vessel re-infarction and ischemia driven target lesion revascularization) was lower in the biolimus stent, driven mostly by a substantial reduction of $80 \%$ in the incidence of target vessel reinfarction. Interestingly, there was a trend towards a lower rate of stent thrombosis in patients with biolimus DES.

It will be interesting to see how newer generation durable polymer DES compare with biodegradable polymer stents. Long-term comparative data between these stent types remain limited and any conclusion is premature at this time [59]. Lastly, due to improved outcomes and reduction in late stent thrombosis with the newer generation DES, the need for DAPT after PCI may be reduced and a major randomized trial is currently underway to determine the optimal duration of DAPT [60]. 


\section{Bleeding risk}

Evidence has accumulated that a higher incidence of bleeding in patients with ACS undergoing revascularization increases mortality [61-63]. Bleeding risk is especially high in patients with an indication for anticoagulation (atrial fibrillation, mechanical valve, venous thromboembolism) that undergo PCI. Results from the WOEST trial indicate that in patients with an established and absolute indication for oral anticoagulant (OAC) who undergo $\mathrm{PCI}, \mathrm{OAC}$ plus clopidogrel is associated with a reduced risk of bleeding with maintained efficacy (no increase in the incidence of myocardial infarction or stent thrombosis) and should therefore be the preferred approach over OAC plus aspirin and clopidogrel [33]. After a 1 year follow up period, there were significantly fewer bleeding events (primary endpoint) in the double therapy group as compared to the triple therapy group (19.4\% vs. $44.4 \%$, HR: 0.36). Future studies are needed in the ACS subset of patients to establish the ideal dose and duration of antithrombotic agents that minimize bleeding without compromising efficacy.

\section{Summary of advances: Updated guidelines}

The ACCF/AHA published new guidelines for management of STEMI [22] and a focused update of the 2007 guidelines for management of NSTEMI/unstable angina in the year 2012 [64]. In the STEMI guidelines, the concept of "door-to-balloon time" was replaced with "first medical contact/FMC-to-device time" similar to European guidelines. There was an increased emphasis on organization of regional systems of care, transfer algorithms and adherence to time to treatments goals. In addition, the use of therapeutic hypothermia in patients with out-of-hospital arrest and STEMI is now given a Class 1 recommendation (IIa in the 2005 guidelines). The major update in NSTEACS guidelines included the incorporation of ticagrelor in the treatment of ACS patients, as previously highlighted.

The ESC guidelines highlight new standards in the system of care (FMC to EKG 10 minutes, FMC to primary PCI in 60 minutes, <90 minutes for transfer from non-PCI center). As previously stated, the guidelines recommend prasugrel and ticagrelor over clopidogrel, and the use of the radial over the femoral route of PCI (only by experienced operators). Lastly, in the updated guidelines, IABP use in STEMI patients was downgraded from $1 \mathrm{C}$ to $2 \mathrm{~B}$.

\section{Abbreviations}

ACS, acute coronary syndrome; ACCF, American College of Cardiology Foundation; AHA, American Heart Association; AMI, acute myocardial infarction; BMS, bare metal stent; CABG, coronary artery bypass grafting; DAPT, dual antiplatelet therapy; DES, drug eluting stent; ESC,
European Society of Cardiology; FMC, first medical contact; IABP, intra-aortic balloon pump; NSTE-ACS, non ST-segment elevation/acute coronary syndrome; NSTEMI, non ST-sequence elevation myocardial infarction; OAC, oral anticoagulant; PAR-1, protease activated receptor-1; PCI, percutaneous coronary intervention; STEMI, ST-segment elevation myocardial infarction.

\section{Disclosure}

The authors declare that they have no disclosures.

\section{References}

I. Rathore SS, Epstein AJ, Volpp KGM, Krumholz HM: Regionalization of care for acute coronary syndromes: more evidence is needed. JAMA 2005, 293:1383-7.

2. Pottenger BC, Diercks DB, Bhatt DL: Regionalization of care for ST-segment elevation myocardial infarction: is it too soon? Ann Emerg Med 2008, 52:677-85.

3. Krumholz HM, Herrin J, Miller LE, Drye EE, Ling SM, Han LF, Rapp MT, Bradley EH, Nallamothu BK, Nsa W, Bratzler DW, Curtis JP: Improvements in door-to-balloon time in the United States, 2005 to 20 I 0. Circulation 20I I, I 24:1038-45.

4. Menees DS, Peterson ED, Wang Y, Curtis JP, Messenger JC, Rumsfeld JS, Gurm HS: Door-to-balloon time and mortality among patients undergoing primary PCI. N Engl J Med 2013, 369:901-9.

\section{FlOOPrime}

RECOMMENDED

5. Fosbol EL, Granger CB, Jollis JG, Monk L, Lin L, Lytle BL, Xian Y, Garvey JL, Mears G, Corbett CC, Peterson ED, Glickman SW: The impact of a statewide pre-hospital STEMI strategy to bypass hospitals without percutaneous coronary intervention capability on treatment times. Circulation 2013, 127:604-12.

\section{FOOOPRIM
RECOMMENDED}

6. Le May MR, Wells GA, So DY, Glover CA, Froeschl M, Maloney J, Dionne R, Marquis J, O'Brien ER, Dick A, Sherrard HL, Trickett J, Poirier $\mathrm{P}$, Blondeau M, Bernick J, Labinaz M: Reduction in mortality as a result of direct transport from the field to a receiving center for primary percutaneous coronary intervention. J Am Coll Cardiol 2012, 60:1223-30.

7. Puymirat E, Simon T, Steg PG, Schiele F, Guéret P, Blanchard D, Khalife K, Goldstein P, Cattan S, Vaur L, Cambou J, Ferrières J, Danchin $\mathrm{N}$ : Association of changes in clinical characteristics and management with improvement in survival among patients with ST-elevation myocardial infarction. JAMA 20I2, 308:998-1006.

8. Armstrong PW, Gershlick AH, Goldstein P, Wilcox R, Danays T, Lambert Y, Sulimov V, Rosell Ortiz F, Ostojic M, Welsh RC, Carvalho AC, Nanas J, Arntz H, Halvorsen S, Huber K, Grajek S, Fresco C, Bluhmki E, Regelin A, Vandenberghe K, Bogaerts K, van de Werf F: Fibrinolysis or primary PCI in ST-segment elevation myocardial infarction. $N$ Engl J Med 2013, 368: |379-87.

\section{FOOOPrime}

\section{RECOMMENDED}

9. Concannon TW, Nelson J, Kent DM, Griffith JL: Evidence of systematic duplication by new percutaneous coronary intervention programs. Circ Cardiovasc Qual Outcomes 2013, 6:400-8.

\section{FlOOPrime} RECOMMENDED

10. Roe MT, Armstrong PW, Fox KAA, White HD, Prabhakaran D, Goodman SG, Cornel JH, Bhatt DL, Clemmensen P, Martinez F, Ardissino D, Nicolau JC, Boden WE, Gurbel PA, Ruzyllo W, Dalby AJ, McGuire DK, Leiva-Pons JL, Parkhomenko A, Gottlieb S, Topacio GO, Hamm C, Pavlides G, Goudev AR, Oto A, Tseng C, Merkely B, 
Gasparovic V, Corbalan R, Cinteză M, et al.: Prasugrel versus clopidogrel for acute coronary syndromes without revascularization. N Engl J Med 2012, 367:1297-309.

\section{FlOOOPrime}

\section{RECOMMENDED}

II. SD Wivott: TRILOGY ACS angiographic cohort: A prospective, randomized trial of prasugrel vs. clopidogrel in patients with non-ST-segment-elevation ACS who are medically managed after coronary angiography [abstract]. Presented at Transcatheter Cardiovascular Therapeutics (TCT) conference 2012 Miami, FL.

12. Montalescot G, Bolognese L, Dudek D, Goldstein P, Hamm C, Tanguay J, Berg JM ten, Miller DL, Costigan TM, Goedicke J, Silvain J, Angioli P, Legutko J, Niethammer M, Motovska Z, Jakubowski JA, Cayla G, Visconti LO, Vicaut E, Widimsky P: Pretreatment with prasugrel in non-ST-segment elevation acute coronary syndromes. $N$ Engl J Med 2013, 369:999-1010.

\section{FlOOOPrime} RECOMMENDED

13. Wallentin L, Becker RC, Budaj A, Cannon CP, Emanuelsson $\mathrm{H}$, Held C, Horrow J, Husted S, James S, Katus H, Mahaffey KW, Scirica BM, Skene A, Steg PG, Storey RF, Harrington RA, Freij A, Thorsén $M$ : Ticagrelor versus clopidogrel in patients with acute coronary syndromes. $N$ Engl J Med 2009, 36 I:1045-57.

\section{FOOOPrime}

14. James SK, Storey RF, Khurmi NS, Husted S, Keltai M, Mahaffey KW, Maya J, Morais J, Lopes RD, Nicolau JC, Pais P, Raev D, Lopez-Sendon JL, Stevens SR, Becker RC: Ticagrelor versus clopidogrel in patients with acute coronary syndromes and a history of stroke or transient ischemic attack. Circulation 20I2, I25:29|4-2I.

15. Wallentin L, James SK, Giannitsis E, Katus HA, Becker RC, Cannon CP, Horrow J, Husted S, Siegbahn A, Steg GP, Storey RF, Wernroth L, Harrington RA: Outcomes with ticagrelor versus clopidogrel in relation to hs troponin-T in non-STE ACS patients managed with early invasive or non-invasive treatment - a PLATO trial substudy [abstract]. Presented at American Heart Association 2012 Scientific Sessions: 3-7 November, 2012 Los Angeles, CA.

16. Leonardi S, Tricoci P, White HD, Armstrong PW, Huang Z, Wallentin L, Aylward PE, Moliterno DJ, van de Werf F, Chen E, Providencia L, Nordrehaug JE, Held C, Strony J, Rorick TL, Harrington RA, Mahaffey $\mathrm{KW}$ : Effect of vorapaxar on myocardial infarction in the thrombin receptor antagonist for clinical event reduction in acute coronary syndrome (TRA.CER) trial. Eur Heart J 2013, 34: $|723-3|$.

\section{FlOOOPrime}

17. Tricoci P, Newby LK, Hasselblad V, Kong DF, Giugliano RP, White HD, Théroux P, Stone GW, Moliterno DJ, van de Werf F, Armstrong PW, Prabhakaran D, Rasoul S, Bolognese L, Durand E, Braunwald E, Califf RM, Harrington RA: Upstream use of small-molecule glycoprotein iib/ iiia inhibitors in patients with non-ST-segment elevation acute coronary syndromes: a systematic overview of randomized clinical trials. Circ Cardiovasc Qual Outcomes 20I I, 4:448-58.

18. Thiele H, Wöhrle J, Hambrecht R, Rittger H, Birkemeyer R, Lauer B, Neuhaus P, Brosteanu O, Sick P, Wiemer M, Kerber S, Kleinertz K, Eitel I, Desch S, Schuler G: Intracoronary versus intravenous bolus abciximab during primary percutaneous coronary intervention in patients with acute ST-elevation myocardial infarction: a randomised trial. Lancet 2012, 379:923-31.

19. Kubica J, Koziński M, Navarese EP, Tantry US, Grześk G, Fabiszak T, Kubica A, Świątkiewicz I, Bliden KP, Gurbel PA: Updated evidence on intracoronary abciximab in ST-elevation myocardial infarction: a systematic review and meta-analysis of randomized clinical trials. Cardiol J 2012, 19:230-42.

20. Stone GW, Maehara A, Witzenbichler B, Godlewski J, Parise H, Dambrink JE, Ochala A, Carlton TW, Cristea E, Wolff SD, Brener S], Chowdhary S, El-Omar M, Neunteufl T, Metzger DC, Karwoski T, Dizon JM, Mehran R, Gibson CM: Intracoronary abciximab and aspiration thrombectomy in patients with large anterior myocardial infarction: the INFUSE-AMI randomized trial. JAMA 2012, 307:1817-26.

\section{FlOOOPrime}

\section{RECOMMENDED}

21. Valgimigli M, Park S, Kim H, Park KW, Park D, Tricoci P, Ferrante G: Benefits and risks of long-term duration of dual antiplatelet therapy after drug-eluting stenting: A meta-analysis of randomized trials. Int J Cardiol 2013, 168:2579-87.

22. O'Gara PT, Kushner FG, Ascheim DD, Casey DE, Chung MK, Lemos JA de, Ettinger SM, Fang JC, Fesmire FM, Franklin BA, Granger CB, Krumholz HM, Linderbaum JA, Morrow DA, Newby LK, Ornato JP, Ou N, Radford MJ, Tamis-Holland JE, Tommaso CL, Tracy CM, Woo YJ, Zhao DX, Anderson JL, Jacobs AK, Halperin JL, Albert NM, Brindis RG, Creager MA, DeMets D, et al.: 2013 ACCF/AHA guideline for the management of ST-elevation myocardial infarction: a report of the American College of Cardiology Foundation/American Heart Association Task Force on Practice Guidelines. J Am Coll Cardiol 20I3, 6I:e78-I40.

\section{FlOOOPrime}

RECOMMENDED

23. Swedish registry questions superiority of bivalirudin over heparin in patients undergoing PCI for NSTE-ACS. [http:// www.escardio.org/about/press/press-releases/pr-I3/Pages/europcr-dayl. aspx - registry]

24. Sabatine MS, Antman EM, Widimsky P, Ebrahim IO, Kiss RG, Saaiman A, Polasek R, Contant CF, McCabe CH, Braunwald E: Otamixaban for the treatment of patients with non-ST-elevation acute coronary syndromes (SEPIA-ACSI TIMI 42): a randomised, double-blind, active-controlled, phase 2 trial. Lancet 2009, 374:787-95.

25. Steg PG, Mehta SR, Pollack CV, Bode C, Cohen M, French WJ, Hoekstra J, Rao SV, Ruzyllo W, Ruiz-Nodar JM, Sabaté M, Widimsky P, Kiss RG, Navarro Estrada JL, Hod H, Kerkar P, Guneri S, Sezer M, Ruda M, Nicolau JC, Cavallini C, Ebrahim I, Petrov I, Kim J, Jeong M, Ramos Lopez GA, Laanmets P, Kovar F, Gaudin C, Fanouillere KC, et al.: Anticoagulation with otamixaban and ischemic events in nonST-segment elevation acute coronary syndromes: the TAO randomized clinical trial. JAMA 2013, 3 10: I 145-55.

\section{FlOOOPrime}

26. Go AS, Mozaffarian D, Roger VL, Benjamin EJ, Berry JD, Borden WB, Bravata DM, Dai S, Ford ES, Fox CS, Franco S, Fullerton HJ, Gillespie C, Hailpern SM, Heit JA, Howard VJ, Huffman MD, Kissela BM, Kittner SJ, Lackland DT, Lichtman JH, Lisabeth LD, Magid D, Marcus GM, Marelli A, Matchar DB, McGuire DK, Mohler ER, Moy CS, Mussolino ME, et al: Heart disease and stroke statistics-20 13 update: a report from the American Heart Association. Circulation 2013, 127:e6-e245.

\section{FlOOOPrime
RECOMMENDED}

27. Mega JL, Braunwald E, Mohanavelu S, Burton P, Poulter R, Misselwitz F, Hricak V, Barnathan ES, Bordes P, Witkowski A, Markov V, Oppenheimer L, Gibson CM: Rivaroxaban versus placebo in patients with acute coronary syndromes (ATLAS ACS-TIMI 46): a randomised, double-blind, phase II trial. Lancet 2009, 374:29-38.

28. Mega JL, Braunwald E, Wiviott SD, Bassand J, Bhatt DL, Bode C, Burton P, Cohen M, Cook-Bruns N, Fox KAA, Goto S, Murphy SA, Plotnikov AN, Schneider D, Sun X, Verheugt FWA, Gibson CM: Rivaroxaban in patients with a recent acute coronary syndrome. $N$ Engl J Med 2012, 366:9-19.

\section{FlOOOPrime}

\section{RECOMMENDED}

29. Mega JL, Braunwald E, Murphy SA, Plotnikov AN, Burton P, Kiss RG, Parkhomenko A, Tendera M, Widimsky P, Gibson CM: Rivaroxaban in patients stabilized after a ST-segment elevation myocardial infarction: results from the ATLAS ACS-2-TIMI-5I trial (Anti-Xa Therapy to Lower Cardiovascular Events in Addition to Standard Therapy in Subjects with Acute Coronary 
Syndrome-Thrombolysis In Myocardial Infarction-5I). J Am Coll Cardiol 2013, 6I:1853-9.

30. FDA Issues Complete Response Letter for XARELTO ${ }^{\circledR}$ (rivaroxaban) for the Reduction of Cardiovascular Events in Patients with Acute Coronary Syndrome. [http://www.prnewswire. $\mathrm{com} /$ news-releases/fda-issues-complete-response-letter-for-xareltorivaroxaban-for-the-reduction-of-cardiovascular-events-in-patients-withacute-coronary-syndrome- $19516269 \mid . h t m l]$

31. Bayer's Xarelto $®$ Approved in the EU for Secondary Prevention after an Acute Coronary Syndrome. [http://press.healthcare. bayer.com/en/press/news-details-page.php/I5050/2013-0292]

32. Oldgren J, Wallentin L, Alexander JH, James S, Jönelid B, Steg G, Sundström J: New oral anticoagulants in addition to single or dual antiplatelet therapy after an acute coronary syndrome: a systematic review and meta-analysis. Eur Heart J 2013, 34: 1670-80.

33. Dewilde WJM, Oirbans T, Verheugt FWA, Kelder JC, Smet BJGL de, Herrman J, Adriaenssens T, Vrolix M, Heestermans AACM, Vis MM, Tijsen JGP, van ' $t$ Hof AW, Berg JM ten: Use of clopidogrel with or without aspirin in patients taking oral anticoagulant therapy and undergoing percutaneous coronary intervention: an openlabel, randomised, controlled trial. Lancet 20I3, 38 I: I |07-I5.

\section{FlOOOPrime RECOMMENDED}

34. Tardif J, Tanguay J, Wright SS, Duchatelle V, Petroni T, Grégoire JC, Ibrahim R, Heinonen TM, Robb S, Bertrand OF, Cournoyer D, Johnson D, Mann J, Guertin M, L'Allier PL: Effects of the P-selectin antagonist inclacumab on myocardial damage after percutaneous coronary intervention for non-ST-segment elevation myocardial infarction: results of the SELECT-ACS trial. J Am Coll Cardiol 201 3, 6 I:2048-55.

\section{FlOOOPrime}

\section{RECOMMENDED}

35. Makkar RR, Smith RR, Cheng K, Malliaras K, Thomson LE], Berman D, Czer LSC, Marbán L, Mendizabal A, Johnston PV, Russell SD, Schuleri KH, Lardo AC, Gerstenblith G, Marbán E: Intracoronary cardiosphere-derived cells for heart regeneration after myocardial infarction (CADUCEUS): a prospective, randomised phase I trial. Lancet 2012, 379:895-904.

\section{FlOOOPrime}

\section{RECOMMENDED}

36. Traverse JH, Henry TD, Pepine CJ, Willerson JT, Zhao DXM, Ellis SG, Forder JR, Anderson RD, Hatzopoulos AK, Penn MS, Perin EC, Chambers J, Baran KW, Raveendran G, Lambert C, Lerman A, Simon DI, Vaughan DE, Lai D, Gee AP, Taylor DA, Cogle CR, Thomas JD, Olson RE, Bowman S, Francescon J, Geither C, Handberg E, Kappenman $C$, Westbrook $L$, et al:: Effect of the use and timing of bone marrow mononuclear cell delivery on left ventricular function after acute myocardial infarction: the TIME randomized trial. JAMA 20I2, 308:2380-9.

37. Sürder D, Manka R, Lo Cicero V, Moccetti T, Rufibach K, Soncin S, Turchetto L, Radrizzani M, Astori G, Schwitter J, Erne P, Zuber M, Maur C auf der, Jamshidi P, Gaemperli O, Windecker S, Moschovitis A, Wahl A, Bühler I, Wyss C, Kozerke S, Landmesser U, Lüscher TF, Corti R: Intracoronary injection of bone marrow-derived mononuclear cells early or late after acute myocardial infarction: effects on global left ventricular function. Circulation 2013, 127:1968-79.

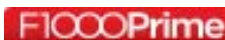

\section{RECOMMENDED}

38. Bolli R: Effect of cardiac stem cells in patients with ischaemic cardiomyopathy (SCIPIO): interim results of the SCIPIO trial upto 2 years after therapy. Presented at American Heart Association, Scientific Sessions: 3-7 November, 20I 2Los Angeles, CA.

39. Thiele H, Zeymer U, Neumann F, Ferenc M, Olbrich H, Hausleiter J, Richardt G, Hennersdorf M, Empen K, Fuernau G, Desch S, Eitel I, Hambrecht R, Fuhrmann J, Böhm M, Ebelt H, Schneider S, Schuler G,
Werdan K: Intraaortic balloon support for myocardial infarction with cardiogenic shock. N Engl J Med 20I2, 367:1287-96.

\section{FIOOOPrime}

40. Jolly SS, Yusuf S, Cairns J, Niemelä K, Xavier D, Widimsky P, Budaj A, Niemelä M, Valentin V, Lewis BS, Avezum A, Steg PG, Rao SV, Gao P, Afzal R, Joyner CD, Chrolavicius S, Mehta SR: Radial versus femoral access for coronary angiography and intervention in patients with acute coronary syndromes (RIVAL): a randomised, parallel group, multicentre trial. Lancet 201 I, 377:1409-20.

\section{FlOOOPrime}

\section{RECOMMENDED}

4I. Mehta SR, Jolly SS, Cairns J, Niemela K, Rao SV, Cheema AN, Steg PG, Cantor WJ, Džavík V, Budaj A, Rokoss M, Valentin V, Gao P, Yusuf S: Effects of radial versus femoral artery access in patients with acute coronary syndromes with or without ST-segment elevation. J Am Coll Cardiol 2012, 60:2490-9.

\section{FIOOOPYIME
RECOMMENDED}

42. Romagnoli E, Biondi-Zoccai G, Sciahbasi A, Politi L, Rigattieri S, Pendenza G, Summaria F, Patrizi R, Borghi A, Di Russo C, Moretti C, Agostoni P, Loschiavo P, Lioy E, Sheiban I, Sangiorgi G: Radial versus femoral randomized investigation in ST-segment elevation acute coronary syndrome: the RIFLE-STEACS (Radial Versus Femoral Randomized Investigation in ST-Elevation Acute Coronary Syndrome) study. J Am Coll Cardiol 2012, 60:248I-9.

\section{FlOOOPrime}

\section{RECOMMENDED}

43. Bernat I, Horak D, Stasek J, Mates M, Ostadal P, Pesek J, Hrabos V Dusek J, Koza J, Sembera Z, Brtko M, Aschermann O, Smid M, Polansky P, Mawiri AA, Bis J, Vojacek J, Costerousse O, Bertrand OF, Rokyta R: A prospective, randomized trial of radial vs. femoral access in patients with ST-Segment elevation myocardial infarction. Presented at Transcatheter Cardiovascular Therapeutics (TCT) conference: 2012 Miami, FL.

44. Feldman DN, Swaminathan RV, Kaltenbach LA, Baklanov DV, Kim LK, Wong SC, Minutello RM, Messenger JC, Moussa I, Garratt KN, Piana RN, Hillegass WB, Cohen MG, Gilchrist IC, Rao SV: Adoption of radial access and comparison of outcomes to femoral access in percutaneous coronary intervention: an updated report from the national cardiovascular data registry (2007-20 I 2). Circulation 2013, 127:2295-306.

45. Hannan EL, Samadashvili Z, Walford G, Holmes DR, Jacobs AK, Stamato NJ, Venditti FJ, Sharma S, King SB: Culprit vessel percutaneous coronary intervention versus multivessel and staged percutaneous coronary intervention for ST-segment elevation myocardial infarction patients with multivessel disease. JACC Cardiovasc Interv 20I0, 3:22-3I.

46. Toma M, Buller CE, Westerhout CM, Fu Y, O'Neill WW, Holmes DR Hamm CW, Granger CB, Armstrong PW: Non-culprit coronary artery percutaneous coronary intervention during acute ST-segment elevation myocardial infarction: insights from the APEX-AMI trial. Eur Heart J 2010, 31:170I-7.

47. Kornowski R, Mehran R, Dangas G, Nikolsky E, Assali A, Claessen BE, Gersh B], Wong SC, Witzenbichler B, Guagliumi G, Dudek D, Fahy M, Lansky AJ, Stone GW: Prognostic impact of staged versus "onetime" multivessel percutaneous intervention in acute myocardial infarction: analysis from the HORIZONS-AMI (harmonizing outcomes with revascularization and stents in acute myocardial infarction) trial. J Am Coll Cardiol 20II, 58:704-II.

48. Wald DS, Morris JK, Wald NJ, Chase AJ, Edwards RJ, Hughes LO, Berry C, Oldroyd KG: Randomized trial of preventive angioplasty in myocardial infarction. $N$ Engl J Med 20|3, 369: I | | 5-23.

\section{FIOOOPrime}

49. Vlaar PJ, Svilaas T, van der Horst IC, Diercks GFH, Fokkema ML, Smet BJGL de, van den Heuvel AFM, Anthonio RL, Jessurun GA, Tan E, Suurmeijer AJH, Zijlstra F: Cardiac death and reinfarction after I year in the Thrombus Aspiration during Percutaneous 
coronary intervention in Acute myocardial infarction Study (TAPAS): a I-year follow-up study. Lancet 2008, 37 I:1915-20.

\section{FlOOOPrime}

50. Sardella G, Mancone M, Bucciarelli-Ducci C, Agati L, Scardala R, Carbone I, Francone M, Di Roma A, Benedetti G, Conti G, Fedele F: Thrombus aspiration during primary percutaneous coronary intervention improves myocardial reperfusion and reduces infarct size: the EXPIRA (thrombectomy with export catheter in infarct-related artery during primary percutaneous coronary intervention) prospective, randomized trial. J Am Coll Cardiol 2009, 53:309-15.

5I. Fröbert O, Lagerqvist B, Olivecrona GK, Omerovic E, Gudnason T, Maeng $M$, Aasa $M$, Angerås $O$, Calais $F$, Danielewicz $M$, Erlinge $D$, Hellsten L, Jensen U, Johansson AC, Kåregren A, Nilsson J, Robertson L, Sandhall L, Sjögren I, Ostlund O, Harnek J, James SK: Thrombus aspiration during ST-segment elevation myocardial infarction. N Engl J Med 2013, 369:1587-97.

\section{FIOOOPrime
RECOMMENDED}

52. Sabate $M$, Cequier $A$, Iñiguez $A$, Serra $A$, Hernandez-Antolin $R$, Mainar $V$, Valgimigli $M$, Tespili $M$, den Heijer $P$, Bethencourt $A$, Vazquez N, Gómez-Hospital JA, Baz JA, Martin-Yuste V, van Geuns R, Alfonso F, Bordes P, Tebaldi M, Masotti M, Silvestro A, Backx B, Brugaletta S, van Es GA, Serruys PW: Everolimus-eluting stent versus bare-metal stent in ST-segment elevation myocardial infarction (EXAMINATION): I year results of a randomised controlled trial. Lancet 2012, 380:|482-90.

53. Hofma SH, Brouwer J, Velders MA, van't Hof AWJ, Smits PC, Queré M, Vries C] de, van Boven AJ: Second-generation everolimus-eluting stents versus first-generation sirolimus-eluting stents in acute myocardial infarction. I-year results of the randomized XAMI (XienceV Stent vs. Cypher Stent in Primary PCI for Acute Myocardial Infarction) trial. J Am Coll Cardiol 20I2, 60:38I-7.

54. Park KW, Kang S, Velders MA, Shin D, Hahn S, Lim W, Yang H, Lee H, van Boven AJ, Hofma SH, Kang H, Koo B, Oh B, Park Y, Kandzari DE, $\mathrm{Kim} \mathrm{H}$ : Safety and efficacy of everolimus- versus sirolimuseluting stents: a systematic review and meta-analysis of I I randomized trials. Am Heart J 20I3, I65:24I-50.e4.

\section{FlOOOPrime}

\section{RECOMMENDED}

55. Palmerini T, Biondi-Zoccai G, Della Riva D, Mariani A, Sabaté $M$, Valgimigli M, Frati G, Kedhi E, Smits PC, Kaiser C, Genereux P, Galatius S, Kirtane AJ, Stone GW: Clinical outcomes with drug-eluting and bare-metal stents in patients with ST-segment elevation myocardial infarction: evidence from a comprehensive network meta-analysis. J Am Coll Cardiol 201 3, 62:496-504.

\section{FlOOPrime \\ RECOMMENDED}

56. Park KW, Lee JM, Kang S, Ahn H, Yang H, Lee H, Kang H, Koo B, Cho J, Gwon H, Lee SY, Chae I, Youn T, Chae JK, Han K, Yu CW, Kim H: Safety and efficacy of second-generation everolimus-eluting Xience $\mathbf{V}$ stents versus zotarolimus-eluting resolute stents in real-world practice: patient-related and stent-related outcomes from the multicenter prospective EXCELLENT and RESOLUTE-Korea registries. J Am Coll Cardiol 2013, 6 I:536-44.
57. Birgelen $C$ von, Basalus $M W Z$, Tandjung $K$, van Houwelingen $K G$, Stoel MG, Louwerenburg JHW, Linssen GCM, Saïd SAM, Kleijne MAWJ, Sen H, Löwik MM, van der Palen J, Verhorst PMJ, Man FHAF de: A randomized controlled trial in second-generation zotarolimuseluting Resolute stents versus everolimus-eluting Xience V stents in real-world patients: the TWENTE trial. J Am Coll Cardiol 2012, 59: |350-6I.

58. Räber L, Kelbæk H, Ostojic M, Ostoijc M, Baumbach A, Heg D, Tüller D, Birgelen C von, Roffi M, Moschovitis A, Khattab AA, Wenaweser P, Bonvini R, Pedrazzini G, Kornowski R, Weber K, Trelle S, Lüscher TF, Taniwaki M, Matter CM, Meier B, Jüni P, Windecker S: Effect of biolimus-eluting stents with biodegradable polymer vs baremetal stents on cardiovascular events among patients with acute myocardial infarction: the COMFORTABLE AMI randomized trial. JAMA 20I2, 308:777-87.

\section{FlOOPrime}

\section{RECOMMENDED}

59. Stefanini GG, Byrne RA, Serruys PW, Waha A de, Meier B, Massberg S, Jüni P, Schömig A, Windecker S, Kastrati A: Biodegradable polymer drug-eluting stents reduce the risk of stent thrombosis at 4 years in patients undergoing percutaneous coronary intervention: a pooled analysis of individual patient data from the ISAR-TEST 3, ISAR-TEST 4, and LEADERS randomized trials. Eur Heart J 2012, 33:|2|4-22.

60. Feres F, Costa RA, Bhatt DL, Leon MB, Botelho RV, King SB, Paula JET de, Mangione JA, Salvadori D, Gusmão MO, Castello $H$, Nicolela E, Perin MA, Devito FS, Marin-Neto JA, Abizaid A: Optimized Duration of clopidogrel therapy following treatment with the endeavor zotarolimus-eluting stent in real-world clinical practice (OPTIMIZE) trial: rationale and design of a large-scale, randomized, multicenter study. Am Heart J 2012, 164:810-6.e3.

6I. Singh M, Rihal CS, Lennon RJ, Spertus JA, Nair KS, Roger VL: Influence of frailty and health status on outcomes in patients with coronary disease undergoing percutaneous revascularization. Circ Cardiovasc Qual Outcomes 201 I, 4:496-502.

62. Steg PG, Huber K, Andreotti F, Arnesen H, Atar D, Badimon L, Bassand J, Caterina R de, Eikelboom JA, Gulba D, Hamon M, Helft G, Fox KAA, Kristensen SD, Rao SV, Verheugt FWA, Widimsky P, Zeymer U, Collet ]: Bleeding in acute coronary syndromes and percutaneous coronary interventions: position paper by the Working Group on Thrombosis of the European Society of Cardiology. Eur Heart J 201 I, 32: 1854-64.

63. Manoukian SV, Feit F, Mehran R, Voeltz MD, Ebrahimi R, Hamon M, Dangas GD, Lincoff AM, White HD, Moses JW, King SB, Ohman EM, Stone GW: Impact of major bleeding on 30-day mortality and clinical outcomes in patients with acute coronary syndromes: an analysis from the ACUITY Trial. J Am Coll Cardiol 2007, 49:I362-8.

64. Jneid H, Anderson JL, Wright RS, Adams CD, Bridges CR, Casey DE, Ettinger SM, Fesmire FM, Ganiats TG, Lincoff AM, Peterson ED, Philippides GJ, Theroux P, Wenger NK, Zidar JP: 2012 ACCFIAHA focused update of the guideline for the management of patients with unstable angina/non-ST-elevation myocardial infarction (updating the 2007 guideline and replacing the $201 \mathrm{I}$ focused update): a report of the American College of Cardiology Foundation/American Heart Association Task Force on Practice Guidelines. J Am Coll Cardiol 2012, 60:645-8I.

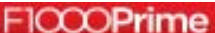

